\title{
Aromatic Hydrocarbon Receptor Suppresses Prostate Cancer Bone Metastasis Cells-Induced Vasculogenesis of Endothelial Progenitor Cells under Hypoxia
}

\author{
Shuai Huang ${ }^{a}$ Yuanqing Guo ${ }^{b}$ Angela Jacobic Ziqing Lia Sheng Huanga \\ Jianan He ${ }^{d}$ Xingmo Liu ${ }^{d}$ Yubo Tange
}

aDepartment of Orthopaedic Surgery, the First Affiliated Hospital of Sun Yat-sen University, Guangzhou, China; ${ }^{b}$ Department of Orthopaedic Surgery, the Fifth Affiliated Hospital of Sun Yat-sen University, Zhuhai, China; 'Biotechnology Center, Technische Universität Dresden, Dresden, Germany; ${ }^{\mathrm{d} D e p a r t m e n t}$ of Orthopaedic Surgery, the Sixth Affiliated Hospital of Sun Yat-sen University, Guangzhou, Guangdong, China; 'Department of Pharmacy, the First Affiliated Hospital of Sun Yat-sen University, Guangzhou, China

\section{Key Words}

Aromatic hydrocarbon receptor • Hypoxia • Vasculogenesis • EPCs • Bone metastasis

\begin{abstract}
Background/Aims: Hypoxia leads to the development of neovascularization in solid tumor by regulating VEGF expression. Aromatic hydrocarbon receptor (AHR), a receptor for dioxinlike compounds, functions as a transcription factor through dimerization with hypoxiainducible factors $1 \beta$ (HIF-1 $\beta$ ) and inhibits the secretion of vascular endothelial growth factor (VEGF). The purpose of this study was to explore whether AHR can suppress hypoxiainduced VEGF production in prostate bone metastasis cells and repress neovascularization in endothelial progenitor cells (EPCs), and, if so, through what mechanisms. Methods: PC-3 or LNCaP cells induced angiogenesis was detected by Matrigel-based tube formation assay, mRNA expression levels was measured by qRT-PCR, VEGF secretion level was determined by ELISA assay, respectively. Results: AHR activation inhibits hypoxia-induced adhesiveness and vasculogenesis of EPCs induced by PC-3 or LNCaP cells under hypoxia. Moreover, AHR activation suppressed hypoxia-induced VEGF production in PC- 3 and LNCaP cells ( $48 \pm 14 \%$ in PC-3, $p=0.000 ; 41 \pm 14 \%$ in LNCaP, $p=0.000$ ) by attenuating HIF- $1 \alpha$ and HIF- $1 \beta$ level that in turn diminished the angiogenic ability of EPCs in vitro. Furthermore, we found the mRNA level of hypoxia-inducible factors $1 \alpha$ (HIF-1 $\alpha)(1.54 \pm 0.13$ fold in PC-3, $p=0.002,1.62 \pm 0.12$ fold in LNCaP, $p=0.001)$ and HIF-1 $(1.67 \pm 0.23$ fold in PC-3, $p=0.007 ; 1.75 \pm 0.26$ fold in LNCaP, $\mathrm{p}=0.008$ ) were upregulated in prostate cancer bone metastasis PC-3 and LNCaP cell lines in response to hypoxia, and revealed that the regulation of VEGF by HIF-1 $\alpha$ and HIF-1 $\beta$ was

S. Huang and Y. Guo contributed equally to this work.


possibly mediated by the activation of phosphatidylinositol 3-kinase pathway. Conclusion: By providing a mechanistic insight into the modulation of neovascularization by AHR ligand, we suggest that AHR ligand has a strong potential of being a new therapeutic agent with applications in the field of bone metastatic prostate cancer.

\section{Introduction}

Prostate cancer (PCa) is the most commonly diagnosed malignant tumor, accounting for the second leading cause of cancer-related deaths in western countries [1], and once tumors metastasize to bone, they are virtually incurable and result in significant morbidity prior to a patient's death $[2,3]$. Neovascularization not only is essential for primary tumor growth, but also facilitates tumor invasion and metastasis [4]. In cancer patients with metastasis, neovascularization-mediated progression of micrometastasis to lethal macrometastasis is the major cause of mortality [5]. In our previous study, we found that treatment of prostate cancer bone metastasis PC-3 cells by hypoxia enhances the migratory and capillary tube formation abilities of human bone marrow derived-endothelial progenitor cells (BM-EPCs) in vitro [6]. Moreover, hypoxia-induced pathological neovascularization was shown to mediate tumor cell dissemination, invasion and metastasis in a zebrafish tumor model [7].

Hypoxia-inducible factors (HIFs) are essential components in regulating transcription of genes that mediate the response to hypoxia. It is reported that cancer cells often show increased levels of HIF- $1 \alpha$ and HIF-2 $\alpha$, especially in aggressive tumor cells [8-10]. Dimerized with a constitutively expressed $\beta$-subunit, HIF- $1 \alpha$ and HIF- $2 \alpha$ regulate expression of target genes in response to hypoxia in different respects [11]. However, the roles of HIF-1 $\alpha$ and HIF- $2 \alpha$ in regulating neovascularization, in PCa bone metastasis under hypoxic conditions remain unclear.

HIF-1 is found overexpressed in various types of cancers and can modulate angiogenesis by regulating VEGF expression [12]. HIF-1 is a heterodimeric transcription factor consisting of two subunits: HIF- $1 \alpha$ and HIF-1 $\beta$, and HIF- $1 \beta$ is also known as aryl hydrocarbon receptor nuclear translocator (ARNT) [13]. Meanwhile, HIF-2 $\alpha$ shows close sequence homology and similar regulatory properties as HIF- $1 \alpha[14,15]$. HIF- $1 \alpha$ is known to be a key regulator of angiogenesis in various types of cancer, and overexpression of HIF- $1 \alpha$ is related with metastasis of human prostate cancer [16-19]. Previous reports suggested that PI3K/Akt is a major cellular signaling hub that plays a key role in numerous cellular functions including proliferation, migration, metabolism, and survival [20]. PI3K regulate the formation of vascular system that is tightly correlated with HIF-1 $\alpha$ expression [21]. Therefore, we thus examine that PI3K signaling is needed for HIF-1-mediated VEGF expression in PCa bone metastasis.

HIF-1 $\beta$, also known as the aryl hydrocarbon nuclear translocator (ARNT), is the heterodimeric partner of HIF- $1 \alpha$ that is involved in a number of cell signaling pathways such as the AHR signaling pathway. AHR belongs to the basic helix-loop-helix/per-HIF$1 \beta$-sim family of transcription factors. Previous studies show that AHR and HIF-1 $\beta$ might collaboratively regulate the carcinogenic process of $\mathrm{PCa}[22,23]$ and AHR can inhibit prostate carcinogenesis and VEGF production in transgenic adenocarcinoma of the mouse prostate $[24,25]$. A further study illustrates the role for AHR in cardiac and vascular development and homeostasis was set up by the generation of AHR-null mice [26]. However, whether AHR plays a role in hypoxia-induced vasculogenesis of BM-EPCs is not fully understood.

In our study, HIF-1 $\alpha$ and HIF-1 $\beta$ was upregulated in response to hypoxia treatment that was associated with enhanced expression of VEGF in PCa bone metastasis PC-3 and LNCaP cell lines. AHR activation suppressed hypoxia-induced VEGF production in PC-3 and LNCaP cells by attenuating HIF- $1 \alpha$ and HIF- $1 \beta$ level, and subsequently, reducing intercellular adhesion between PC-3 and EPCs, and diminished the tube formation capacity of EPCs. Moreover, we present evidence supporting that regulation of VEGF by HIF- $1 \alpha$ and HIF- 


\section{Cellular Physiology Cell Physiol Biochem 2016;39:709-720 \begin{tabular}{l|l} 
DOI: 10.1159/000445662 & $\begin{array}{l}\text { O 2016 The Author(s). Published by S. Karger AG, Basel } \\
\text { www.karger.com/cpb }\end{array}$
\end{tabular} \\ Huang et al.: AHR Suppresses Vasculogenesis under Hypoxia}

$1 \beta$, but not HIF-2 $\alpha$, in response to hypoxia through phosphatidylinositol 3-kinase (PI3K) activation. These results provide new clues to understand the molecular mechanisms of the HIF pathway in the regulation of neovasculogenesis in PCa bone metastasis and show the possibility of developing novel therapeutics targeting tumor neovascularization.

\section{Materials and Methods}

\section{Cell culture}

The bone metastatic PCa cell line PC-3 and LNCaP cell lines were purchased from the American Type Culture Collection (ATCC; Manassas, VA), and maintained in F-12 medium (Hyclone) and RPMI 1640 medium (Gibco, Invitrogen) separately supplemented with 10\% fetal bovine serum, $100 \mathrm{mg} / \mathrm{ml}$ streptomycin, and 100 units/mlpenicillin. For normoxia experiments, the PC-3 and LNCaP cells were cultured at $37^{\circ} \mathrm{C}$ with $5 \% \mathrm{CO}_{2} / 95 \%$ air in a humidified incubator, and for hypoxia experiments, the PC-3 and LNCaP cells were cultured at $37^{\circ} \mathrm{C}$ with $5 \% \mathrm{CO}_{2}, 94 \% \mathrm{~N}_{2}$, and $1 \% \mathrm{O}_{2}$ in a multigas incubator (Juji Field, Tokyo, Japan).

BM-EPCs were isolated from bone marrow blood of male patients with lumbar degenerative diseases (age range, 48-81 years; mean age $53.8 \pm 16.9$ years) at the time of operation as previously report [6]. Informed consent was obtained from the patients, and all procedures were performed in accordance with the guidance and approval of a research Ethics Committee at the First Affiliated Hospital of Sun Yat-sen University (NO. 2008-55).

\section{Cell-cell adhesion assay}

To characterize the possible effect of hypoxia on cell-cell adhesion, PC-3 cells were grown overnight to a confluent monolayer. In addition, EPCs were treated as indicated for $48 \mathrm{~h}$ and fluorescence-labeled with calcein acetoxymethyl (AM) (Molecular Probes, Invitrogen, CA, USA) for $1 \mathrm{~h}$ at $37^{\circ} \mathrm{C}$ followed by washing with PBS. These cells were then plated onto the established cell monolayer (PC-3 cells). Attachment and spreading of the plated cells were monitored and recorded after $20 \mathrm{~min}$ by a fluorescence microscopy. Quantification of intercellular adhesion was performed by counting the number of cells per microscopic field of view that remained attached after three gentle washing steps with PBS.

\section{BM-EPCs tube formation assay}

The co-cultures on matrigel system was used to assess angiogenic capability of PC-3 and LNCaP cells. Briefly, PC-3 and LNCaP cells were embeded in $100 \mu \mathrm{L}$ liquid matrigel and seeded into 96-well plates. After overnight incubation, $5 \times 10^{3} \mathrm{EPCs}$ in $100 \mu \mathrm{L}$ of the complete medium were introduced onto the top of the solidified PC-3 and LNCaP matrigel suspension. The co-cultures on matrigel were inspected and photographed at $18 \mathrm{~h}$ following the overlaid of EPCs under an inverted light microscope at 200x magnification. Five independent fields were detected for each well and the average number of tubes/field was calculated.

Small interference RNA (siRNA) transfection

siRNA were designed using Invitrogen BOCK-iT RNAi designer and targeted to HIF-1 $\alpha$, HIF-1 $\beta$, HIF$2 \alpha$ : Before transfections, $2 \times 10^{5}$ cells were seeded per well of 6 -well plates for $24 \mathrm{~h}$. After that, siRNAs were transfected with Lipofectamine 2000 (Invitrogen, Carlsbad, CA, USA) according to the manufacturer's instructions. Cellular levels of the mRNA specific for the siRNA transfection were checked by quantitative real-time RT-PCR (qRT-PCR), and all experiments were performed $48 \mathrm{~h}$ after transfection.

\section{Quantitative Real-time PCR}

Total RNA was isolated from PC-3 and LNCaP cells using the Trizol reagent (Invitrogen) according to the manufacturer's instructions. cDNA was amplified under cycling conditions of $95^{\circ} \mathrm{C}$ for $3 \mathrm{~min}$, followed by 40 cycles of $95^{\circ} \mathrm{C}$ for $30 \mathrm{~s}, 60^{\circ} \mathrm{C}$ for $30 \mathrm{~s}$, and $72^{\circ} \mathrm{C}$ for $60 \mathrm{~s}$. Real-time PCR analysis was performed using the iQ5 Real Time PCR Detection System (Bio-Rad). Relative expression values of HIF-1 $\alpha$, HIF-1 $\beta$, HIF- $2 \alpha$, VEGF, AHR and GAPDH from three independent experiments were calculated following the $2^{-\Delta \Delta \mathrm{Ct}}$ method of Schmittgen and Livak [27]. 


\section{Cellular Physiology Cell Physiol Biochem 2016;39:709-720 and Biochemistry Published online: July 25, $2016 \quad \begin{aligned} & \text { DOI: 10.1159/000445662 } 2016 \text { The Author(s). Published by S. Karger AG, Basel } \\ & \text { www.karger.com/cpb }\end{aligned}$ \\ Huang et al.: AHR Suppresses Vasculogenesis under Hypoxia}

Enzyme-Linked Immunosorbent Assay (ELISA) for VEGF

ELISA was performed using VEGF ELISA kit (Excell, Shanghai, China) as previously described [20]. Briefly, the supernatants of PC-3 and LNCaP cells were collected and detected by ELISA assay, according to the manufacturer's protocol. $50 \mu \mathrm{L}$ of supernatants incubated with dilution buffer (50 $\mu \mathrm{L} /$ well) and incubation buffer ( $50 \mu \mathrm{L} /$ well) at room temperature for $2 \mathrm{~h}$ in a 96-well plate. The 96-well plate was washed 4 times with wash buffer and incubated with biotin conjugate $(100 \mu \mathrm{L} /$ well $)$ at room temperature for $1 \mathrm{~h}$. After washing, stabilized chromogen $(100 \mu \mathrm{L} /$ well) was used to incubate in the dark for 30 min at room temperature. At the end, stop solution $(100 \mu \mathrm{L} /$ well $)$ was used and the absorbance was detected at $450 \mathrm{~nm}$.

\section{Statistical analysis}

Data were analyzed using a Student's t-test on SPSS 17.0 (SPSS, Inc., Chicago, IL, USA) Software, and One-way ANOVA was performed for comparing more than two groups. Each result was obtained from at least three independent experiments and the experimental data are presented as the means \pm standard deviation from at least three individual experiments. $p<0.05$ was considered statistically significant for all tests.

\section{Results}

AHR suppresses the adhesiveness and vasculogenesis of EPCs induced by PC-3 or LNCaP cells under hypoxia

Using a lentiviral transduction system, we successfully overexpressed the AHR in PC-3 and LNCaP cells (Fig. 1A). Consequently, cells with high expression of AHR showed lower number of adherent cells and tubes on Matrigel under hypoxia as compared to control cells (Fig. 1E, 2A and 2E). To further enlighten the role of HIF-1 on capillary tube formation of BM-EPCs, cells were silenced with HIF- $1 \alpha$, HIF- $1 \beta$ or HIF- $2 \alpha$ by siRNA transfection. RT-PCR was performed to ensure adequate knocking down of HIF- $1 \alpha$, HIF-1 $\beta$ or HIF-2 $\alpha$ (Fig. 1B, 1C and 1D). As shown in Fig. 1F, 2B and 2F, knockdown of HIF-1 $\alpha$ or HIF-1 $\beta$ also dramatically decreased the ability of adhesion and tube formation by EPCs. In contrast, low expression of HIF- $2 \alpha$ had no significant effect on intercellular adhesion and tube formation of EPCs.

The PI3K pathways are known for regulating cell growth, cell survival and endothelial cell angiogenesis [28]. In our study, the inhibition of PI3K with LY294002 significantly diminished the capacity of intercellular adhesion between PC-3 and EPCs, and lowered the capability of EPCs to form tubular network in vitro. Further study utilized VEGFR2 inhibitor DMH4 also showed suppressive effect on cell adhesion and angiogenesis, suggesting that PI3K signaling pathway may be involved in angiogenesis under hypoxic conditions (Fig. 1G, $2 \mathrm{C}$ and $2 \mathrm{G}$ ).

AHR expression and activation inhibits hypoxia-induced VEGF expression in PC-3 and LNCaP cells

AHR was reported in the previous studies to participate in the inhibition of hypoxiainduced VEGF production and prostate carcinogenesis [24, 25]. Therefore we examined whether AHR signaling activation suppressed hypoxia-induced VEGF transcription in PC-3 and LNCaP cells. Consequently, hypoxia-induced VEGF expression was significantly declined in AHR transfected cells (Fig. 3A and 3C). Furthermore, activation of the AHR signaling pathway by the specific AHR agonist 3-methylcholanthrene (3-MC) also efficiently suppressed hypoxia-induced VEGF mRNA transcription (Fig. 3B and 3D). The combined data supported that activation of AHR signaling repressed VEGF expression in PC-3 and LNCaP cells under hypoxic conditions.

HIF- $1 \alpha$ and HIF-1 $\beta$ are required for hypoxia-induced VEGF expression

Previous studies have suggested that hypoxia stimulates HIF- $1 \alpha$ and VEGF expression in PCa bone metastasis cell [29]. HIF-1 $\beta$ is an essential dimerization partner of HIF-1 $\alpha$ to form an active transcription complex, which is able to regulate VEGF expression under hypoxia. 


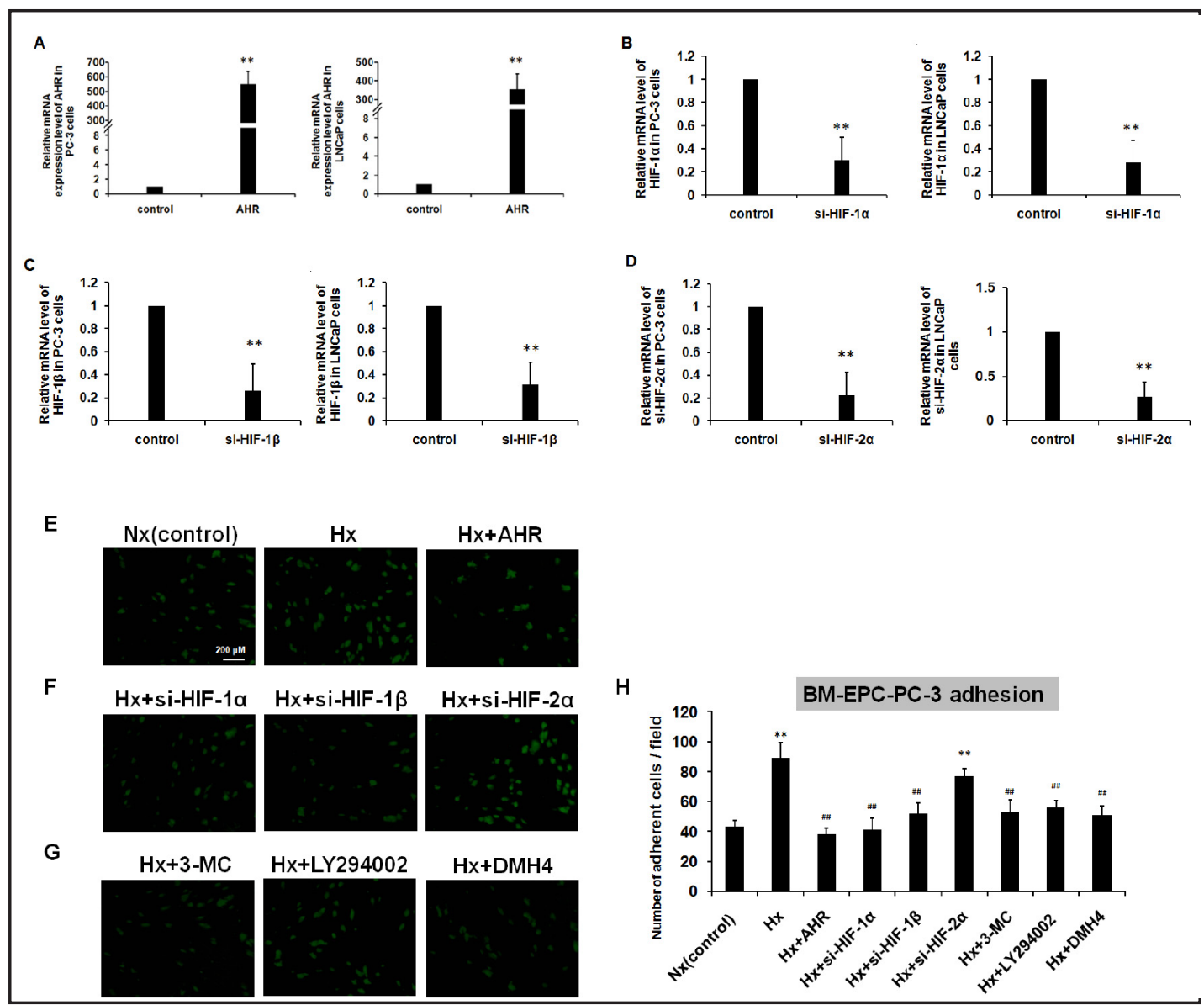

Fig. 1. AHR activation inhibits VEGF-induced adhesiveness of EPCs by hypoxia in PC-3 cells. (A) PC-3 and LNCaP cells were transfected with AHR expression vectors or control vectors. AHR mRNA levels were measured by real-time PCR. (B-D) PC-3 or LNCaP cells were transfected with specific HIF-1 $\alpha$, HIF-1 $\beta$ or HIF- $2 \alpha$ siRNA. $48 \mathrm{~h}$ after transfection, mRNA expression were measured to determine the efficiency of the silence. (E-H) EPCs were treated as indicated for $48 \mathrm{~h}$ and fluorescence-labeled with calcein acetoxymethyl (AM) for $1 \mathrm{~h}$, followed by washing with PBS. These cells were then plated onto the established PC-3 monolayer. Attachment and spreading of the plated cells were monitored and recorded after 20 min by fluorescence microscopy. Quantification of intercellular adhesion was performed by counting the number of cells per microscopic field of view that remained attached after three gentle washing steps with PBS. ${ }^{* *} p<0.01$ vs. normoxia (control). ${ }^{\# \#} p<0.01$ vs. hypoxia only.

To further demonstrate the role of HIF- $1 \alpha$ or HIF-1 $\beta$ in regulating hypoxia-induced VEGF expression in PC-3 and LNCaP cells, we used specific siRNA to silence their expression. As shown in Fig. 4A and 5A, mRNA expression of HIF- $1 \alpha$ and HIF- $1 \beta$ were increased under hypoxia compared with normoxia. In particular, the HIF- $1 \alpha /$ HIF- $1 \beta$ expression in PC-3 and LNCaP cells under hypoxic conditions was revealed to be inhibited when HIF- $1 \alpha /$ HIF- $1 \beta$ was knocked down by siRNA. In addition, an increased transcriptional level of VEGF was confirmed under hypoxic conditions (Fig. 4B and 5B). And the expression of VEGF in PC-3 and LNCaP cells under hypoxic conditions was revealed to be inhibited when the cells were knocked down by HIF- $1 \alpha$ or HIF-1 $\beta$ (Fig. 4C and 5 C). These results strongly suggested that HIF- $1 \alpha$ and HIF-1 $\beta$ were required for hypoxia-induced VEGF expression.

HIF-2 $\alpha$ does not directly regulate the expression of VEGF

HIF- $1 \alpha$ and HIF- $2 \alpha$ are considered to be potential targets for tumor therapy since they regulate the expression of genes that participate in the tumor cell survival, angiogenesis,

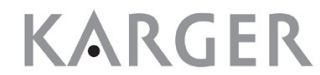




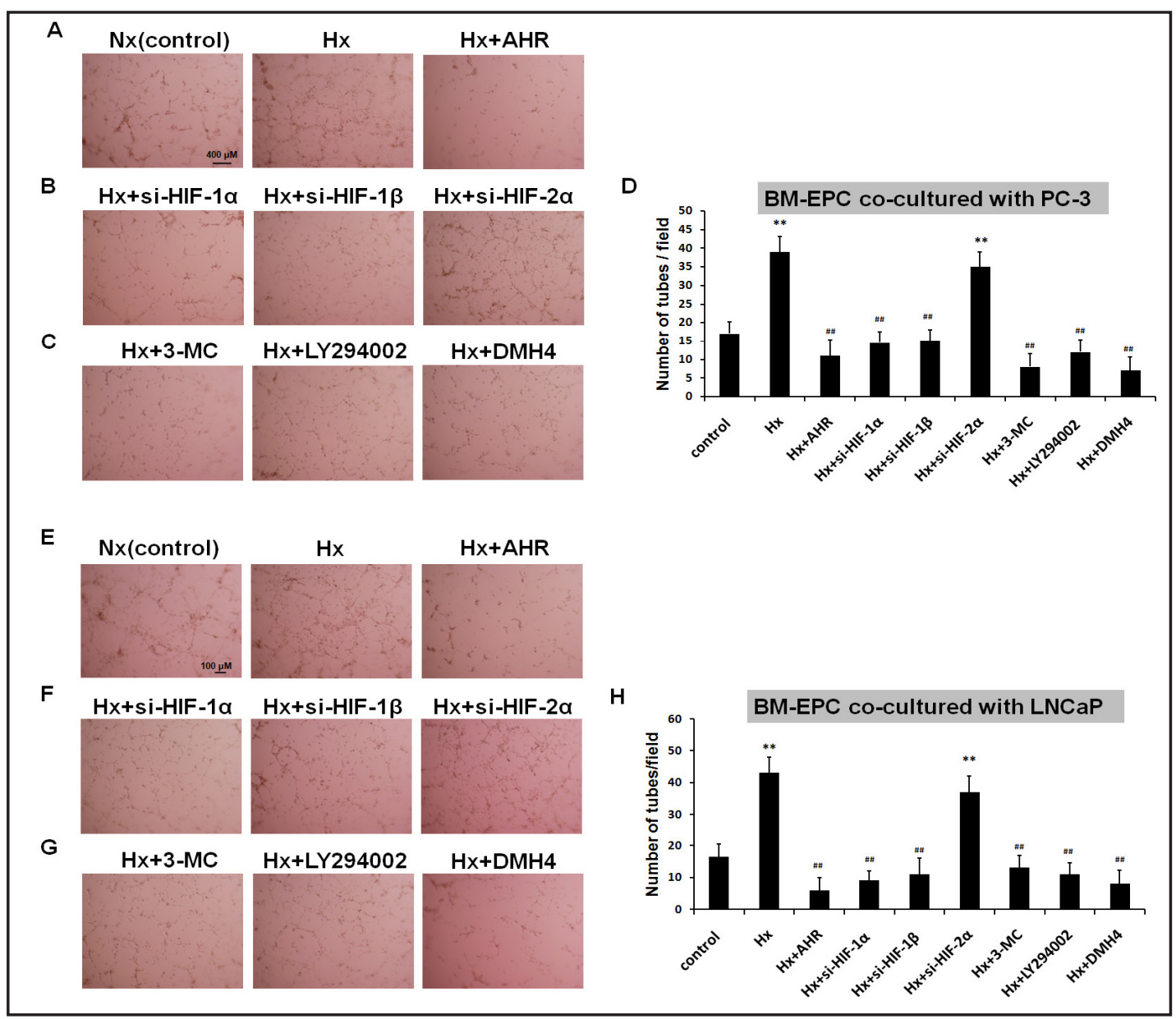

Fig. 2. AHR activation inhibits VEGF-induced vasculogenesis of EPCs by hypoxia in PC-3 and LNCaP cells. (A-D) PC-3 cells were embeded in matrigel and seeded into 96-well plates. After overnight incubation, EPCs were introduced onto the top of the solidified PC-3 matrigel suspension. The co-cultures on matrigel were inspected and photographed at $18 \mathrm{~h}$ following the overlaid of EPCs under an inverted light microscope at $200 \times$ magnification. Five independent fields were detected for each well and the average number of tubes/ field was calculated. (E-H) The similar methods were also used to observe LNCaP cells. ${ }^{* *} p<0.01$ vs. normoxia (control). ${ }^{\# \#} p<0.01$ vs. hypoxia only.

and aggressiveness. To determine the contribution of HIF-2 $\alpha$ to VEGF expression, mRNA expression of VEGF subject to hypoxia was examined in PC-3 cells. As shown in Fig. 6A, mRNA expression of HIF- $2 \alpha$ was increased under hypoxia compared with normoxia. In particular, HIF- $2 \alpha$ expression in PC-3 and LNCaP cells under hypoxic conditions was revealed to be declined when HIF- $2 \alpha$ was knocked down by siRNA. In addition, the increased transcriptional level of VEGF was confirmed under hypoxic conditions. But the expression of VEGF was revealed to be not affected when cells were silenced with HIF- $2 \alpha$ under hypoxic conditions (Fig. 6B and 6C). These results strongly suggested that compared with the heterodimer of HIF- $1 \alpha$ and HIF-1 $\beta$, HIF- $2 \alpha$ was not required for hypoxia-induced VEGF expression.

PI3K regulates HIF-1 $\alpha$ signaling and mediates hypoxia-induced VEGF expression

Cellular proliferation and survival require the involvement of phosphoinositide 3-kinase (PI3-K)/Akt pathways. And PI3K may act as an upstream regulator of HIF-1 $\alpha$ expression in various tumor cells including PCa cells [30-35]. Therefore, we hypothesized that PI3K signaling was required for HIF-1-mediated VEGF expression in PC-3 and LNCaP cells.

\section{KARGER}




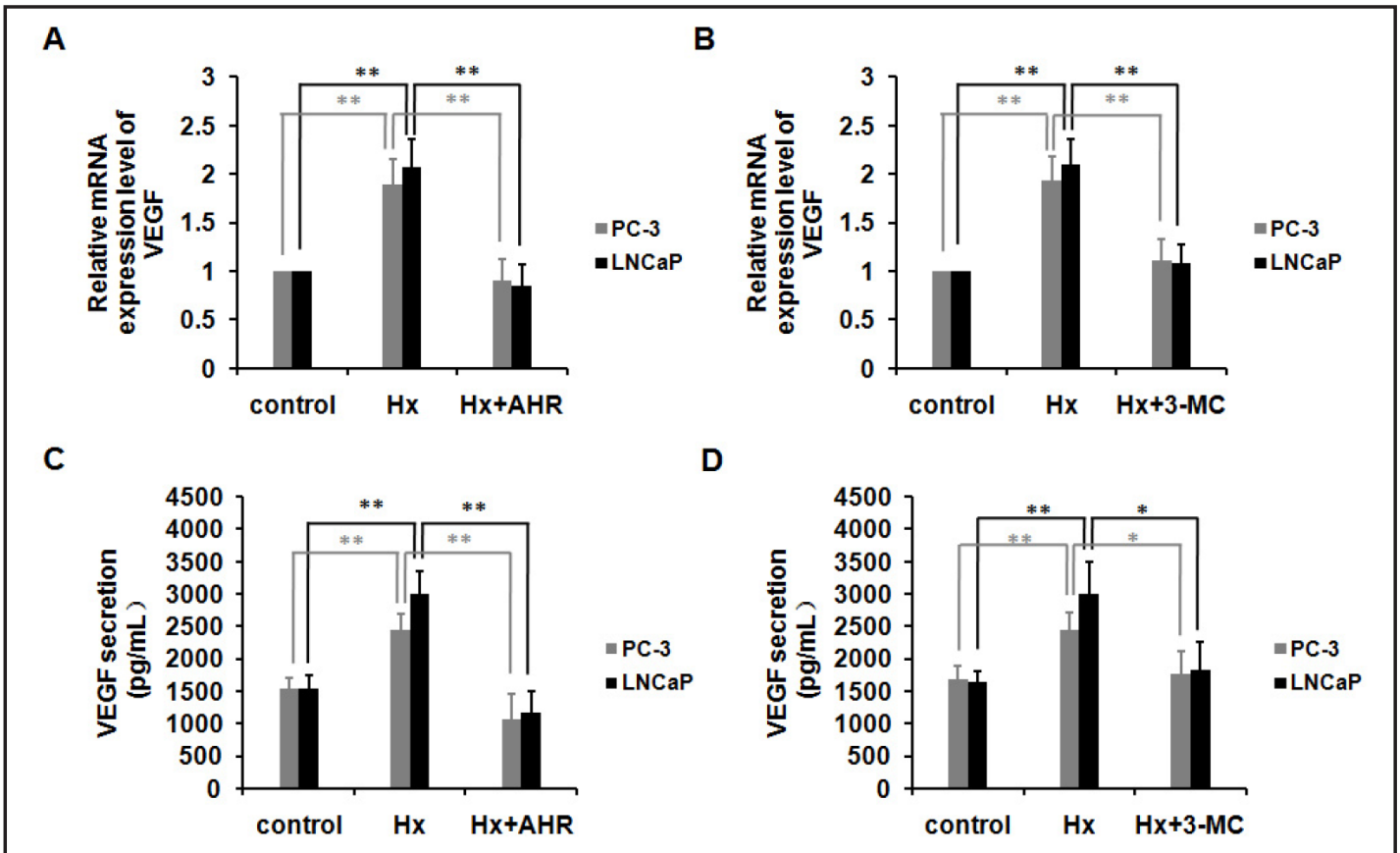

Fig. 3. AHR inhibits hypoxia-induced VEGF expression in PC-3 and LNCaP cells. Serum-starved PC-3 and LNCaP cells were pretreated with $1 \mu \mathrm{M}$ of the selective AHR modulator 3-methylcholanthrene (3-MC), or the solvent control, DMSO, for $6 \mathrm{~h}$ and then cultured under hypoxia or normoxia for $12 \mathrm{~h}$. The relative mRNA expression levels of VEGF were determined by real-time PCR, and the VEGF secretion was detected by ELISA. ${ }^{*} p<0.05 ;{ }^{* *} p<0.01$.

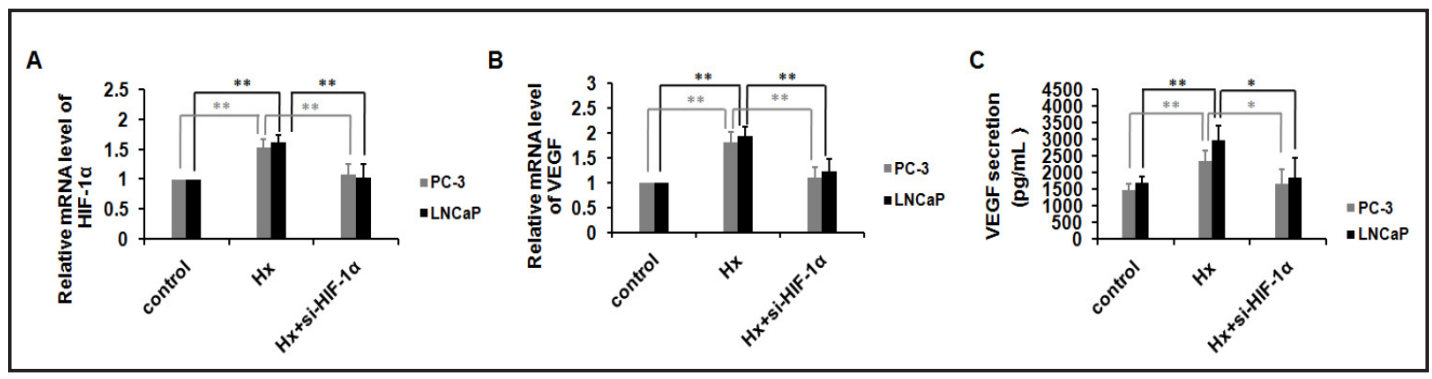

Fig. 4. The role of HIF- $1 \alpha$ in hypoxia-induced VEGF expression in PC-3 and LNCaP cells. PC-3 or LNCaP cells were incubated in the absence or presence of HIF-1 $\alpha$ siRNA for $48 \mathrm{~h}$. Then cells were cultured under normoxic or hypoxic conditions for another $48 \mathrm{~h}$. The relative mRNA expression levels of VEGF were determined by real-time PCR, and the VEGF secretion was detected by ELISA. ${ }^{*} p<0.05 ;^{* *} p<0.01$.

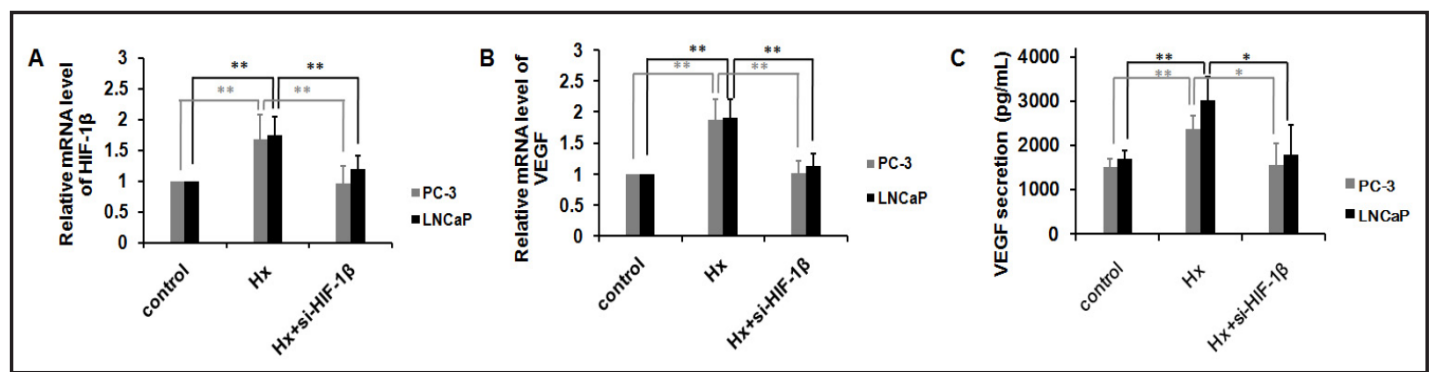

Fig. 5. The role of HIF-1 $\beta$ in hypoxia-induced VEGF expression in PC-3 and LNCaP cells. PC-3 or LNCaP cells were incubated in the absence or presence of HIF-1 $\beta$ siRNA for $48 \mathrm{~h}$. Then cells were cultured under normoxic or hypoxic conditions for another $48 \mathrm{~h}$. The relative mRNA expression levels of VEGF were determined by real-time PCR, and the VEGF secretion was detected by ELISA. ${ }^{*} p<0.05 ;{ }^{* *} p<0.01$.

\section{KARGER}




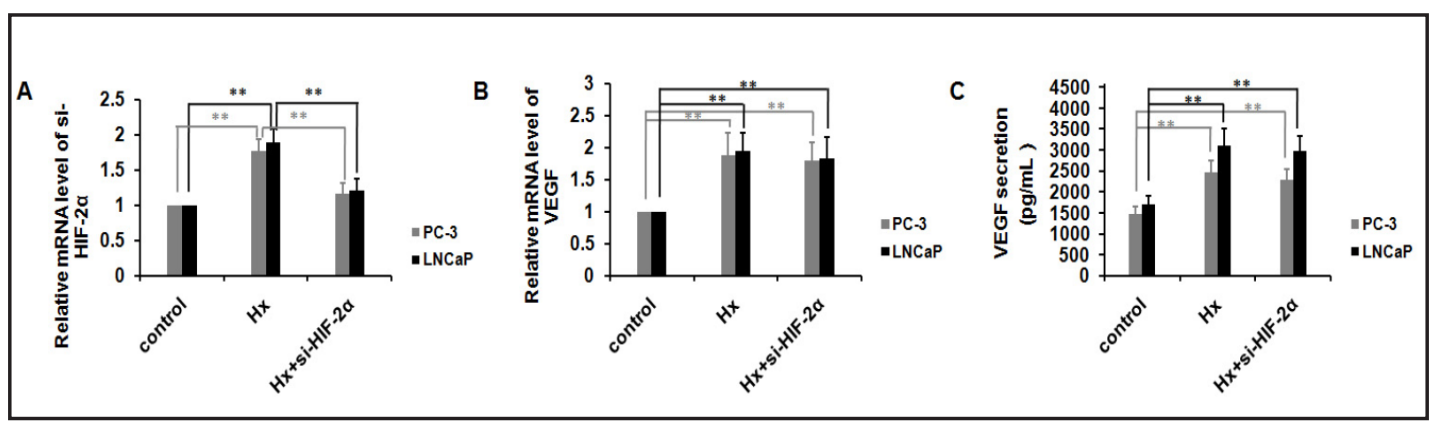

Fig. 6. The role of HIF- $2 \alpha$ in hypoxia-induced VEGF expression in PC-3 and LNCaP cells. PC-3 or LNCaP cells were incubated in the absence or presence of HIF- $2 \alpha$ siRNA for $48 \mathrm{~h}$. Then cells were cultured under normoxic or hypoxic conditions for another $48 \mathrm{~h}$. The relative mRNA expression levels of VEGF were determined by real-time PCR, and the VEGF secretion was detected by ELISA. ${ }^{* *} p<0.01$.

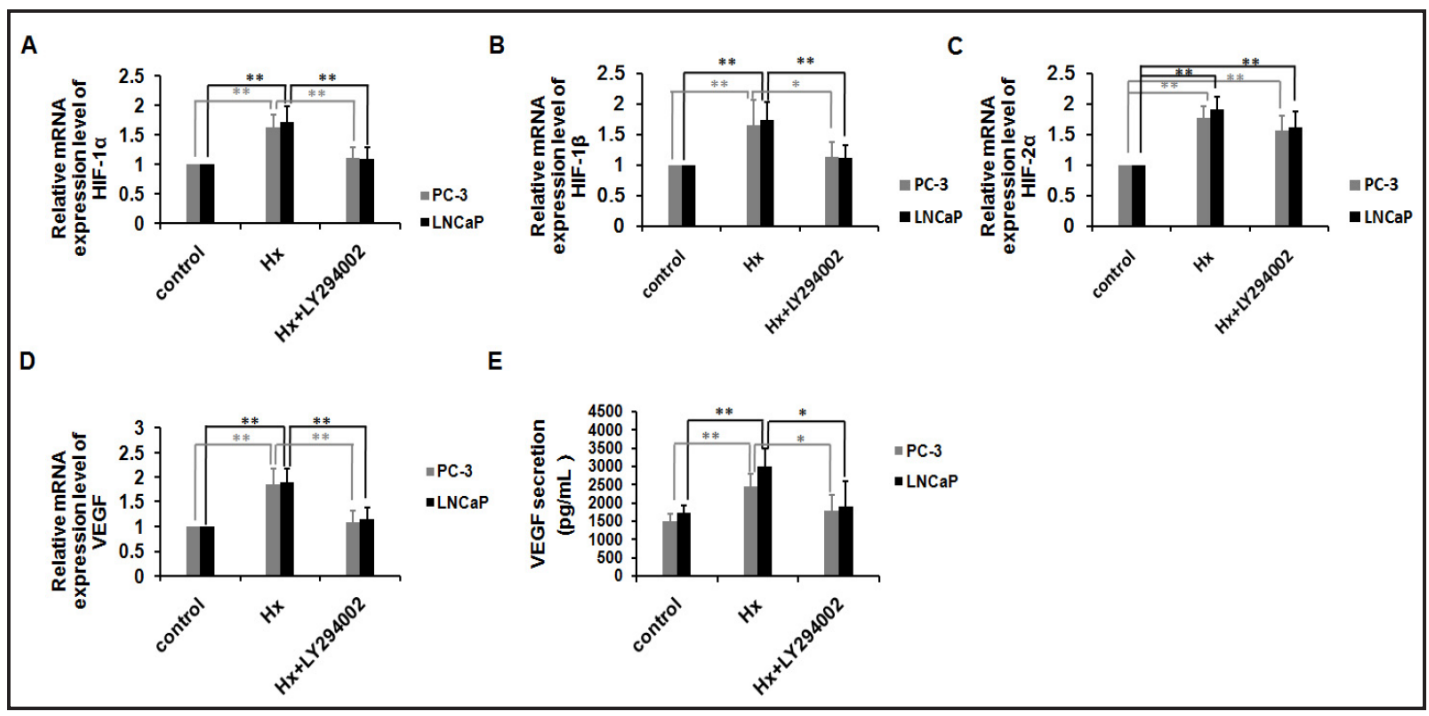

Fig. 7. PI3K regulates HIF-1 $\alpha$ signaling and mediates hypoxia-induced VEGF expression Serum-starved PC-3 and LNCaP cells were pretreated with $10 \mu \mathrm{M}$ of LY294002 or the solvent control DMSO for $1 \mathrm{~h}$ and then cultured under hypoxic or normoxic conditions. The relative mRNA expression levels of HIF-1 $\alpha$ (A), HIF-1 $\beta$ (B), HIF- $2 \alpha(C)$ and VEGF (D) were determined by real-time PCR. VEGF secretion (E) was determined by ELISA. ${ }^{*} p<0.05 ;{ }^{* *} p<0.01$.

To determine whether PI3K signaling plays a role in hypoxia-induced HIF- $1 \alpha$ expression, cells were pretreated with a specific inhibitor of P13K, LY294002, and then cultured under hypoxia. The expression of HIF- $1 \alpha$, HIF- $1 \beta$ and HIF- $2 \alpha$ was then examined by qRT-PCR. As shown in Fig. 7A-7C, treatment with the PI3K inhibitor LY294002 showed an inhibition on hypoxia-induced HIF- $1 \alpha$ and HIF-1 $\beta$ expression. However, the expression of HIF- $2 \alpha$ was not affected by LY294002 treatment. These data reveal that PI3K was required for hypoxiainduced HIF- $1 \alpha$ and HIF-1 $\beta$ expression. Moreover, hypoxia-induced VEGF expression was also significantly suppressed in case of blockage of PI3K activity (Fig. 7D and 7E). These results suggested that PI3K acts upstream of HIF-1 $\alpha$ signaling underlying the action of hypoxia-induced VEGF expression.

\section{Discussion}

Hypoxia, as a key inducer of neovascularization in tumors [36], leads to increased expression of VEGF [29], which is correlates with increasing grade, vascularity, and 


\section{Cellular Physiology Cell Physiol Biochem 2016;39:709-720

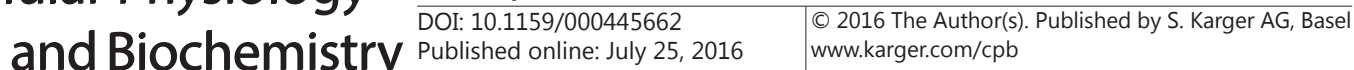 \\ Huang et al.: AHR Suppresses Vasculogenesis under Hypoxia}

tumorigenicity that expressed by prostate cancer at a high level [37, 38]. Indeed, antiangiogenic agents applying for anti-tumor therapies targeting VEGF has proven to be clinically efficacious [39]. In this study, we demonstrated that AHR activation inhibits hypoxia-induced adhesiveness and vasculogenesis of EPCs induced by PC-3 or LNCaP cells under hypoxia through targeting VEGF and HIF-1 $\alpha$ expression. Mechanistically, we found that these effects involve the PI3K signaling pathway. Although HIF-2 $\alpha$ was overexpressed under hypoxic conditions, it was found not significantly affect VEGF expression in PCa bone metastasis cell lines in the current study.

The adhesion of circulating tumor cells to vascular endothelial cells is one of the key steps for metastasis because it can protect tumor cells from anoikis, fluid shear force, and attack from the immune system [40]. The results of the present study indicated that AHR remarkably suppressed hypoxia-induced heterotypic adhesion between EPCs and PC-3 cells, which implies that the decreased endothelial-PC-3 adhesion may contribute to the abridged angiogenic and metastatic effect exerted by AHR. Furthermore, the inhibition of endothelialPC-3 adhesion after knockdown of HIF- $1 \alpha$ and HIF- $1 \beta$ suggests those effects are HIF- $1 \alpha$ and HIF-1 $\beta$-dependent.

Recent studies have shown that EPCs contribute significantly to tumor growth and metastatisation [5, 41, 42]. Meanwhile, blood levels of EPCs tend to increase in cancer patients and has a strong association with the stage of malignant disease [43]. In our previous published papers, we found that treatment of PC- 3 cells by hypoxia enhances the migratory and tube formation abilities of BM-EPCs in vitro [6]. Therefore, anti-angiogenic treatments targeting VEGF signaling in EPCs may facilitate anti-tumor effects in cancer patients [44]. In the present study, our data confirm that hypoxia significantly enhanced the tube formation of EPCs induced by PC-3 and LNCaP cells, which can be suppressed significantly by the VEGFR2 inhibitor DMH4. These results strongly suggest that hypoxia-induced VEGF expression play an important role in tube formation of EPC, and those effects are HIF- $1 \alpha$ and HIF-1 $\beta$ dependent. Furthermore, AHR also inhibited vasculogenesis of EPCs effectively through the crosstalk between HIF-1 $\beta$, which is dependent on hypoxia-induced VEGF signaling pathways. In all, those results suggested a role of AHR as a tumor suppressor in PCa bone metastasis, that is similar to the effects previously reported in heart and breast cancer.

Ablation of AHR results in enhancement of ischemia-induced angiogenesis, which may be caused by an increased abundance and activity of the HIF-1-ARNT heterodimer. This effect is likely attributed to the associated enhancement of ischemia-induced VEGF expression [45]. Activation of AHR can inhibit prostate tumor metastasis in TRAMP mice [24]. Moreover, hypoxia-induced signaling is involved in AHR activity in breast cancer cells and hepatocarcinoma cells [46]. The results in the current work revealed that AHR, significantly inhibited the expression of VEGF both in PC-3 and LNCaP cells, and the activation of AHR facilitate the inhibition of VEGF induced by hypoxia, indicating that HIF- $1 \beta$ (ARNT) is a dimerization partner of HIF-1 $\alpha$ in hypoxia-induced signaling as mentioned above. These results suggested that reciprocal crosstalk may exist between AHR and hypoxia signaling pathways as some reports mentioned $[47,48]$. We hypothesized that AHR may undermine the interaction of HIF- $1 \beta$ with HIF- $1 \alpha$, and then inhibit hypoxia-induced VEGF expression in PCa bone metastasis cell lines.

HIF- $1 \alpha$ and HIF- $2 \alpha$ are the two major isoforms of the $\alpha$-subunit in hypoxia, and share a high degree of sequence homology. Previous reports show that HIF- $1 \alpha$ belongs to the PerArnt-Sim (PAS) family of basic helix-loop-helix transcription factors and dimerizes with HIF$1 \beta$ to form the HIF-1 complex, which then potentiated VEGF expression by directly binding to the VEGF promoter in response to hypoxic conditions. Our data confirm that hypoxia significantly enhanced the expression of HIF- $1 \alpha$ at protein level in PCa bone metastasis cell lines, which is consistent with previous evidence in LNCaP cells $[49,50]$. The AHR, a ligand-activated transcription factor, also contains a basic helix-loop-helix motif and functions together with the AHR nuclear translocator (ARNT), which is identical to HIF-1 3 . Hypoxia-induced VEGF expression is HIF-1 $\beta$-dependent and HIF- $1 \beta$ is needed for normal AHR functions. Similar to HIF-1 $\alpha$, our results showed that the expression of HIF-1 $1 \beta$ protein 


\section{Cellular Physiology Cell Physiol Biochem 2016;39:709-720 \begin{tabular}{l|l} 
DOI: 10.1159/000445662 & $\begin{array}{l}\text { O 2016 The Author(s). Published by S. Karger AG, Basel } \\
\text { www.karger.com/cpb }\end{array}$ \\
\cline { 2 - 3 } Published online: July 25,2016 Biochemistry
\end{tabular} \\ Huang et al.: AHR Suppresses Vasculogenesis under Hypoxia}

was also increased by hypoxia treatment. In addition, VEGF expression was suppressed by interfering with both HIF- $1 \alpha$ and HIF-1 $\beta$ in human PCa bone metastasis cell lines under hypoxia. Meanwhile, we found LY294002, a specific PI3K inhibitor, enhanced the inactivation of HIF- $1 \alpha$ in hypoxic conditions, and inhibited hypoxia-induced VEGF expression in PC-3 and LNCaP cells. These findings highlight the crucial role of HIF-1/VEGF system as a target for anti-angiogenic and anti-cancer therapy in human PCa bone metastasis cell lines under hypoxia [51-53]. Taken together, AHR, potentially as an anti-angiogenic agent, can apply for anti-tumor therapies targeting VEGF-induced neovasculogenesis under hypoxia in PCa bone metastasis. Additional in-depth experiments are needed to further demonstrate the role of AHR in the inhibition of tumor progress in vivo.

\section{Acknowledgements}

This work was supported by grants from the National Natural Science Foundation of China (No.81402227) and Guangdong Natural Science Foundation (No. 2014A030310157).

\section{Disclosure Statement}

None.

\section{References}

1 Nelson WG, De Marzo AM, Isaacs WB: Prostate cancer. N Engl J Med 2003;349:366-381.

2 Roodman GD: Mechanisms of bone metastasis. N Engl J Med 2004;350:1655-1664.

3 Mundy GR: Metastasis to bone: causes, consequences and therapeutic opportunities. Nat Rev Cancer 2002;2:584-593.

4 Weidner N, Semple JP, Welch WR, Folkman J: Tumor angiogenesis and metastasis--correlation in invasive breast carcinoma. N Engl J Med 1991;324:1-8.

5 Gao D, Nolan DJ, Mellick AS, Bambino K, McDonnell K, Mittal V: Endothelial progenitor cells control the angiogenic switch in mouse lung metastasis. Science 2008;319:195-198.

6 Huang S, Peng L, Tang Y, Zhang L, Guo W, Zou X, Peng X: Hypoxia of PC-3 prostate cancer cells enhances migration and vasculogenesis in vitro of bone marrow-derived endothelial progenitor cells by secretion of cytokines. Oncol Rep 2013;29:2369-2377.

7 Lee SL, Rouhi P, Dahl Jensen L, Zhang D, Ji H, Hauptmann G, Ingham P, Cao Y: Hypoxia-induced pathological angiogenesis mediates tumor cell dissemination, invasion, and metastasis in a zebrafish tumor model. Proc Natl Acad Sci USA 2009;106:19485-19490.

8 Khandrika L, Lieberman R, Koul S, Kumar B, Maroni P, Chandhoke R, Meacham RB, Koul HK: Hypoxiaassociated p38 mitogen-activated protein kinase-mediated androgen receptor activation and increased HIF-1alpha levels contribute to emergence of an aggressive phenotype in prostate cancer. Oncogene 2009;28:1248-1260.

9 Rankin EB, Giaccia AJ: The role of hypoxia-inducible factors in tumorigenesis. Cell Death Differ 2008;15:678-685.

10 Tian H, Huang P, Zhao Z, Tang W, Xia J: HIF-1alpha plays a role in the chemotactic migration of hepatocarcinoma cells through the modulation of CXCL6 expression. Cell Physiol Biochem 2014;34:15361546.

11 Hu CJ, Wang LY, Chodosh LA, Keith B, Simon MC: Differential roles of hypoxia-inducible factor 1alpha (HIF1alpha) and HIF-2alpha in hypoxic gene regulation. Mol Cell Biol 2003;23:9361-9374.

12 Pugh CW, Ratcliffe PJ: Regulation of angiogenesis by hypoxia: role of the HIF system. Nat Med 2003;9:677684.

13 Rodriguez-Jimenez FJ, Moreno-Manzano V: Modulation of hypoxia-inducible factors (HIF) from an integrative pharmacological perspective. Cell Mol Life Sci 2012;69:519-534. 


\section{Cellular Physiology Cell Physiol Biochem 2016;39:709-720 \begin{tabular}{ll|l} 
DOI: 10.1159/000445662 & $\begin{array}{l}\text { @ } 2016 \text { The Author(s). Published by S. Karger AG, Basel } \\
\text { www.karger.com/cpb }\end{array}$ \\
\hline
\end{tabular}

14 Wiesener MS, Turley H, Allen WE, Willam C, Eckardt KU, Talks KL, Wood SM, Gatter KC, Harris AL, Pugh CW, Ratcliffe PJ, Maxwell PH: Induction of endothelial PAS domain protein-1 by hypoxia: characterization and comparison with hypoxia-inducible factor-1alpha. Blood 1998;92:2260-2268.

15 Giatromanolaki A, Koukourakis MI, Sivridis E, Turley H, Talks K, Pezzella F, Gatter KC, Harris AL: Relation of hypoxia inducible factor 1 alpha and 2 alpha in operable non-small cell lung cancer to angiogenic/ molecular profile of tumours and survival. Br J Cancer 2001;85:881-890.

16 Lawrence YR, Dicker AP: Hypoxia in prostate cancer: observation to intervention. Lancet Oncol 2008;9:308-309.

17 Bolat F, Haberal N, Tunali N, Aslan E, Bal N, Tuncer I: Expression of vascular endothelial growth factor (VEGF), hypoxia inducible factor 1 alpha (HIF-1alpha), and transforming growth factors beta1 (TGFbeta1) and beta3 (TGFbeta3) in gestational trophoblastic disease. Pathol Res Pract 2010;206:19-23.

18 Kallergi G, Markomanolaki H, Giannoukaraki V, Papadaki MA, Strati A, Lianidou ES, Georgoulias V, Mavroudis D, Agelaki S: Hypoxia-inducible factor-1alpha and vascular endothelial growth factor expression in circulating tumor cells of breast cancer patients. Breast Cancer Res 2009;11:R84.

19 Nanko N, Tanikawa M, Mase M, Fujita M, Tateyama H, Miyati T, Yamada K: Involvement of hypoxia-inducible factor-1alpha and vascular endothelial growth factor in the mechanism of development of chronic subdural hematoma. Neurol Med Chir (Tokyo) 2009;49:379-385.

20 Huang S, He P, Peng X, Li J, Xu D, Tang Y: Pristimerin Inhibits Prostate Cancer Bone Metastasis by Targeting PC-3 Stem Cell Characteristics and VEGF-Induced Vasculogenesis of BM-EPCs. Cell Physiol Biochem 2015;37:253-268.

21 Jiang BH, Zheng JZ, Aoki M, Vogt PK: Phosphatidylinositol 3-kinase signaling mediates angiogenesis and expression of vascular endothelial growth factor in endothelial cells. Proc Natl Acad Sci USA 2000;97:17491753.

22 Sommer RJ, Sojka KM, Pollenz RS, Cooke PS, Peterson RE: Ah receptor and ARNT protein and mRNA concentrations in rat prostate: effects of stage of development and 2,3,7,8-tetrachlorodibenzo-p-dioxin treatment. Toxicol Appl Pharmacol 1999;155:177-189.

23 Kashani M, Steiner G, Haitel A, Schaufler K, Thalhammer T, Amann G, Kramer G, Marberger M, Scholler A: Expression of the aryl hydrocarbon receptor (AhR) and the aryl hydrocarbon receptor nuclear translocator (ARNT) in fetal, benign hyperplastic, and malignant prostate. Prostate 1998;37:98-108.

24 Fritz WA, Lin TM, Peterson RE: The aryl hydrocarbon receptor (AhR) inhibits vanadate-induced vascular endothelial growth factor (VEGF) production in TRAMP prostates. Carcinogenesis 2008;29:1077-1082.

25 Fritz WA, Lin TM, Cardiff RD, Peterson RE: The aryl hydrocarbon receptor inhibits prostate carcinogenesis in TRAMP mice. Carcinogenesis 2007;28:497-505.

26 Fernandez-Salguero PM, Ward JM, Sundberg JP, Gonzalez FJ: Lesions of aryl-hydrocarbon receptor-deficient mice. Vet Pathol 1997;34:605-614.

27 Livak KJ, Schmittgen TD: Analysis of relative gene expression data using real-time quantitative PCR and the 2(T)(-Delta Delta C) method. Methods 2001;25:402-408.

28 Sheppard K, Kinross KM, Solomon B, Pearson RB, Phillips WA: Targeting PI3 kinase/AKT/mTOR signaling in cancer. Crit Rev Oncog 2012;17:69-95.

29 Bao B, Ahmad A, Kong D, Ali S, Azmi AS, Li Y, Banerjee S, Padhye S, Sarkar FH: Hypoxia induced aggressiveness of prostate cancer cells is linked with deregulated expression of VEGF, IL-6 and miRNAs that are attenuated by CDF. PLoS One 2012;7:e43726.

30 Fukuda R, Hirota K, Fan F, Jung YD, Ellis LM, Semenza GL: Insulin-like growth factor 1 induces hypoxiainducible factor 1-mediated vascular endothelial growth factor expression, which is dependent on MAP kinase and phosphatidylinositol 3-kinase signaling in colon cancer cells. J Biol Chem 2002;277:3820538211.

31 Segrelles C, Ruiz S, Santos M, Martinez-Palacio J, Lara MF, Paramio JM: Akt mediates an angiogenic switch in transformed keratinocytes. Carcinogenesis 2004;25:1137-1147.

32 Befani CD, Vlachostergios PJ, Hatzidaki E, Patrikidou A, Bonanou S, Simos G, Papandreou CN, Liakos P: Bortezomib represses HIF-1alpha protein expression and nuclear accumulation by inhibiting both PI3K/ Akt/TOR and MAPK pathways in prostate cancer cells. J Mol Med (Berl) 2012;90:45-54.

33 Park KY, Lee HJ, Jeong SJ, Lee HJ, Kim HS, Kim SH, Lim S, Kim HC, Lu J, Kim SH: 1,2,3,4,6-Penta-0-gallolybeta-D-glucose suppresses hypoxia-induced accumulation of hypoxia-inducible factor-1alpha and signaling in LNCaP prostate cancer cells. Biol Pharm Bull 2010;33:1835-1840. 


\section{Cellular Physiology Cell Physiol Biochem 2016;39:709-720 \begin{tabular}{l|l} 
DOI: 10.1159/000445662 & $\begin{array}{l}\text { O 2016 The Author(s). Published by S. Karger AG, Basel } \\
\text { www.karger.com/cpb }\end{array}$
\end{tabular} \\ Huang et al.: AHR Suppresses Vasculogenesis under Hypoxia}

34 Manohar SM, Padgaonkar AA, Jalota-Badhwar A, Sonawane V, Rathos MJ, Kumar S, Joshi KS: A novel inhibitor of hypoxia-inducible factor-1alpha P3155 also modulates PI3K pathway and inhibits growth of prostate cancer cells. BMC Cancer 2011;11:338.

35 Jiang BH, Jiang G, Zheng JZ, Lu Z, Hunter T, Vogt PK: Phosphatidylinositol 3-kinase signaling controls levels of hypoxia-inducible factor 1. Cell Growth Differ 2001;12:363-369.

36 Liao D, Johnson RS: Hypoxia: a key regulator of angiogenesis in cancer. Cancer Metastasis Rev 2007;26:281-290.

37 Ferrer FA, Miller LJ, Lindquist R, Kowalczyk P, Laudone VP, Albertsen PC, Kreutzer DL: Expression of vascular endothelial growth factor receptors in human prostate cancer. Urology 1999;54:567-572.

38 Weidner N, Carroll PR, Flax J, Blumenfeld W, Folkman J: Tumor angiogenesis correlates with metastasis in invasive prostate carcinoma. Am J Pathol 1993;143:401-409.

39 Ferrara N, Hillan KJ, Novotny W: Bevacizumab (Avastin), a humanized anti-VEGF monoclonal antibody for cancer therapy. Biochem Biophys Res Commun 2005;333:328-335.

40 Zhang JP, Li N, Bai WZ, Qiu XC, Ma BA, Zhou Y, Fan QY, Shan LQ: Notch ligand Delta-like 1 promotes the metastasis of melanoma by enhancing tumor adhesion. Braz J Med Biol Res 2014;47:299-306.

41 Gao D, Nolan D, McDonnell K, Vahdat L, Benezra R, Altorki N, Mittal V: Bone marrow-derived endothelial progenitor cells contribute to the angiogenic switch in tumor growth and metastatic progression. Biochim Biophys Acta 2009;1796:33-40.

42 Martin-Padura I, Gregato G, Marighetti P, Mancuso P, Calleri A, Corsini C, Pruneri G, Manzotti M, Lohsiriwat V, Rietjens M, Petit JY, Bertolini F: The White Adipose Tissue Used in Lipotransfer Procedures Is a Rich Reservoir of CD34(+) Progenitors Able to Promote Cancer Progression. Cancer Res 2012;72:325-334.

43 Döme B, Hendrix MJC, Paku S, Tovari J, Timar J: Alternative vascularization mechanisms in cancer Pathology and therapeutic implications. Am J Pathol 2007;170:1-15.

44 Moccia F, Zuccolo E, Poletto V, Cinelli M, Bonetti E, Guerra G, Rosti V: Endothelial progenitor cells support tumour growth and metastatisation: implications for the resistance to anti-angiogenic therapy. Tumour Biol 2015;36:6603-6614.

45 Ichihara S, Yamada Y, Ichihara G, Nakajima T, Li P, Kondo T, Gonzalez FJ, Murohara T: A role for the aryl hydrocarbon receptor in regulation of ischemia-induced angiogenesis. Arterioscler Thromb Vasc Biol 2007;27:1297-1304.

46 Wolff M, Jelkmann W, Dunst J, Depping R: The Aryl Hydrocarbon Receptor Nuclear Translocator (ARNT/ HIF-1beta) is influenced by hypoxia and hypoxia-mimetics. Cell Physiol Biochem 2013;32:849-858.

47 Fleming CR, Billiard SM, Di Giulio RT: Hypoxia inhibits induction of aryl hydrocarbon receptor activity in topminnow hepatocarcinoma cells in an ARNT-dependent manner. Comp Biochem Physiol C Toxicol Pharmacol 2009;150:383-389.

48 Jensen KA, Luu TC, Chan WK: A truncated Ah receptor blocks the hypoxia and estrogen receptor signaling pathways: a viable approach for breast cancer treatment. Mol Pharm 2006;3:695-703.

49 Lee DH, Lee YJ: Quercetin suppresses hypoxia-induced accumulation of hypoxia-inducible factor-1alpha (HIF-1alpha) through inhibiting protein synthesis. J Cell Biochem 2008;105:546-553.

50 Park SS, Bae I, Lee YJ: Flavonoids-induced accumulation of hypoxia-inducible factor (HIF)-1alpha/2alpha is mediated through chelation of iron. J Cell Biochem 2008;103:1989-1998.

51 Wang GL, Jiang BH, Rue EA, Semenza GL: Hypoxia-inducible factor 1 is a basic-helix-loop-helix-PAS heterodimer regulated by cellular 02 tension. Proc Natl Acad Sci U S A 1995;92:5510-5514.

52 Ke Q Costa M: Hypoxia-inducible factor-1 (HIF-1). Mol Pharmacol 2006;70:1469-1480.

53 Reyes H, Reisz-Porszasz S, Hankinson O: Identification of the Ah receptor nuclear translocator protein (Arnt) as a component of the DNA binding form of the Ah receptor. Science 1992;256:1193-1195. 